\title{
Microbial and pathological findings in farmed Atlantic salmon Salmo salar with proliferative gill inflammation
}

\author{
T. Steinum ${ }^{1, *}$, A. Kvellestad ${ }^{1,3}$, D. J. Colquhoun ${ }^{1}$, M. Heum ${ }^{1}$, S. Mohammad ${ }^{1}$, \\ R. Nygaard Grøntvedt ${ }^{2,4}$, K. Falk ${ }^{1}$ \\ ${ }^{1}$ Section for Fish Health, National Veterinary Institute, Oslo, Norway \\ ${ }^{2}$ Marine Harvest Norway AS, Bergen, Norway \\ ${ }^{3}$ Present address: Department for Basal Sciences and Aquatic Medicine, Norwegian School of Veterinary Science, Oslo, Norway \\ ${ }^{4}$ Present address: Section for Environmental and Biosecurity Measures, National Veterinary Institute, Trondheim, Norway
}

\begin{abstract}
Proliferative gill inflammation (PGI) is an important cause of loss in seawater-farmed Atlantic salmon in Norway. Several microbes have been associated with PGI, including the commonly but not exclusively observed inclusions (epitheliocysts) within the gill lamellae related to infection with 'Candidatus Piscichlamydia salmonis'. Atlantic salmon transferred in the spring of 2004 to 12 seawater farms situated in mid- and southwest Norway were sampled throughout that year. Outbreaks of PGI, as evaluated by clinical examination, histology, and mortality data, were diagnosed in 6 of 7 farms in southwest Norway but not in the 5 farms studied in mid-Norway. Generally, mortality started 3 to 5 mo after seawater transfer and outbreaks lasted at least 1 to 3 mo. 'Ca. P. salmonis' was detected by real-time PCR only in fish from PGI-affected farms and our results indicate an association between 'Ca. P. salmonis' load and PGI severity. Likewise, although widely distributed in all 12 farms studied, epitheliocyst prevalence and number per fish as observed by histology appears associated with PGI prevalence and severity. However, the occurrence of epitheliocysts showed no association with molecular detection of ' $\mathrm{Ca}$. P. salmonis', suggesting that at least 1 other organism is responsible for many of the observed inclusions. A microsporidian, Desmozoon lepeophtherii, was identified at high prevalence regardless of fish and farm PGI status, but at higher loads in fish with PGI. Our results support a multifactorial etiology for PGI in which 'Ca. P. salmonis', an unidentified epitheliocyst agent, and the microsporidian are contributing causes. No evidence for the involvement of Atlantic salmon paramyxovirus in PGI development was identified in the present study. High water temperatures and ectoparasites probably exacerbated mortality.
\end{abstract}

KEY WORDS: Proliferative gill inflammation · Epitheliocysts · 'Candidatus Piscichlamydia salmonis' · Desmozoon lepeophtherii · 'Candidatus Clavochlamydia salmonicola' · Atlantic salmon paramyxovirus

Resale or republication not permitted without written consent of the publisher

\section{INTRODUCTION}

Identification of etiological agents involved in gill disease is often challenging as the fish gill may be exposed to environmental pollutants (Evans 1987), disease-provoking organisms in the environment, or unfavorable water quality (Speare \& Ferguson 2006, Rodger 2007). The term proliferative gill inflammation (PGI) was, therefore, introduced to best describe a ser- ious recurring gill disease affecting seawater-farmed Atlantic salmon Salmo salar in Norway (Kvellestad et al. 2005) with an obvious multifactorial etiology. A PGI diagnosis is based on observed pathological changes, i.e. a combination of circulatory disturbances, epithelial cell death, epithelial hyperplasia, and inflammation. PGI occurs most commonly in southwest Norway, typically in the first autumn following spring seawater transfer of smolts, and outbreaks may last from weeks 
to months (Kvellestad et al. 2004, Skjelstad et al. 2007). Mortality varies and losses of 15 to $20 \%$ or higher have been reported (Flesjå et al. 2004, Kvellestad et al. 2004). Estimation of economic losses is difficult, but one of the largest farming companies in Norway considered PGI to be the disease responsible for most losses in terms of both numbers of fish and biomass in 2007 (Skjelstad et al. 2007). Gill disorders were also the most important cause of losses in Ireland in 2005 (Rodger 2007). Previous studies have indicated a multifactorial etiology behind PGI, following identification of various microorganisms occurring alone or in combination with others, including Atlantic salmon paramyxovirus (ASPV) (Kvellestad et al. 2003, 2005), salmon gill poxvirus (Nylund et al. 2008), various ectoparasites (Kvellestad et al. 2005), as well as lamellar bacterial inclusions (epitheliocystis) (Nylund et al. 1998). Recently, the microsporidian parasite Desmozoon lepeophtherii (Freeman \& Sommerville 2009, Nylund et al. 2010) has been detected in gills and other organs in Atlantic salmon with PGI and other diseases. A previous epidemiological study (Grøntvedt et al. 2006) identified water quality as a potential risk factor for development of PGI. The involvement of putative etiological agents is generally difficult to determine for this type of disease affecting an organ constantly exposed to the environment, and has, therefore, not been extensively studied. Given the combination of unresolved etiology with common clinical and pathological features, the term PGI has been and remains an appropriate means to describe the observed condition.

Epitheliocystis was originally defined as the presence of bacterial basophilic granular inclusions (epitheliocysts) within the cytoplasm of gill and/or skin epithelial cells, in association with pathological change in surrounding tissues (Hoffman et al. 1969). While epitheliocysts have been recognized worldwide for years in several species of marine and freshwater fish (Nowak \& Lapatra 2006), epitheliocystis with associated proliferative responses and inflammation of the gill epithelium has only been reported in cultured fish (Paperna 1977, Molnár \& Boros 1981, Miyazaki et al. 1986, Crespo et al. 1990, Nylund et al. 1998).

Chlamydia-like organisms (CLOs) have, on the basis of electron microscopy, been considered the causative agents of epitheliocysts (Hoffman et al. 1969, Paperna et al. 1978, 1981, Molnár \& Boros 1981, Paperna \& Alves de Matos 1984, Nylund et al. 1998), but have never been cultured nor have Koch's postulates been fulfilled. This has hampered both characterization of the agents and elucidation of their precise role in gill disease. Only recently have molecular advances allowed description of some CLOs associated with epitheliocysts, e.g. 'Candidatus Piscichlamydia salmonis' ('Ca. P. salmonis') in seawater-farmed Atlantic salmon with gill disease from Ireland and Norway (Draghi et al. 2004), and 'Candidatus Clavochlamydia salmonicola' ('Ca. C. salmonicola', Karlsen et al. 2008) and a Neochlamydia-like sp. (Draghi et al. 2007) in freshwater salmonids. Partial genomic sequences from CLOs in silver perch Bidyanus bidyanus, barramundi Lates calcarifer, and leafy sea dragon Phycodurus eques illustrate the diversity of such organisms in fish, as these had higher similarity values with Chlamydialike bacteria isolated from humans, pigs, or water storage than with each other (Meijer et al. 2006).

In the absence of infection models the etiological significance of different agents has to be examined by other methods. The main aim of the present study was, therefore, to study PGI development in Atlantic salmon following seawater transfer by histopathology and the involvement of 'Ca. P. salmonis' and ASPV by realtime PCR. Samples from freshwater juvenile production units supplying smolts to the studied seawater farms were also examined. Finally, selected samples were examined by real-time PCR for the presence of the microsporidian Desmozoon lepeophtherii.

\section{MATERIALS AND METHODS}

Tissue sampling and storage. The fish were sampled in 2004 from 6 freshwater hatcheries and 12 seawater farms (designated A to $M$ ) in mid and southwest Norway (Fig. 1). Sampling was performed once in freshwater in April prior to seawater transfer and thereafter until an outbreak was confirmed, which resulted in a variable number of sampling points at flexible time intervals from each farm between June and December. Independent of the present study, the fish were observed continually by farm staff and were regularly inspected by local fish health services. Samples from fish displaying clinical signs of disease were submitted to the National Veterinary Institute for histological investigation. Planned sampling during periods with no suspicion of disease and no increased mortality comprised 17 to 20 fish caught with a dip net from the surface. The second left gill arch was fixed in $10 \%$ buffered formalin for later processing and a piece of the third left gill arch was collected in RNAlater ${ }^{\mathrm{TM}}$ (Ambion) for PCR screening. Following cage-side observation of respiratory distress, an extended sampling was performed including fixation of additional organs in formalin and kidney tissues in RNAlater from 2 to 10 apparently healthy and 7 to 10 fish displaying respiratory distress. Subsequent analyses focused mainly on sea-farmed post-smolt groups suffering PGI, for which samples from the freshwater stage also were available. In these cases all collected gill samples from every time point were examined. In 


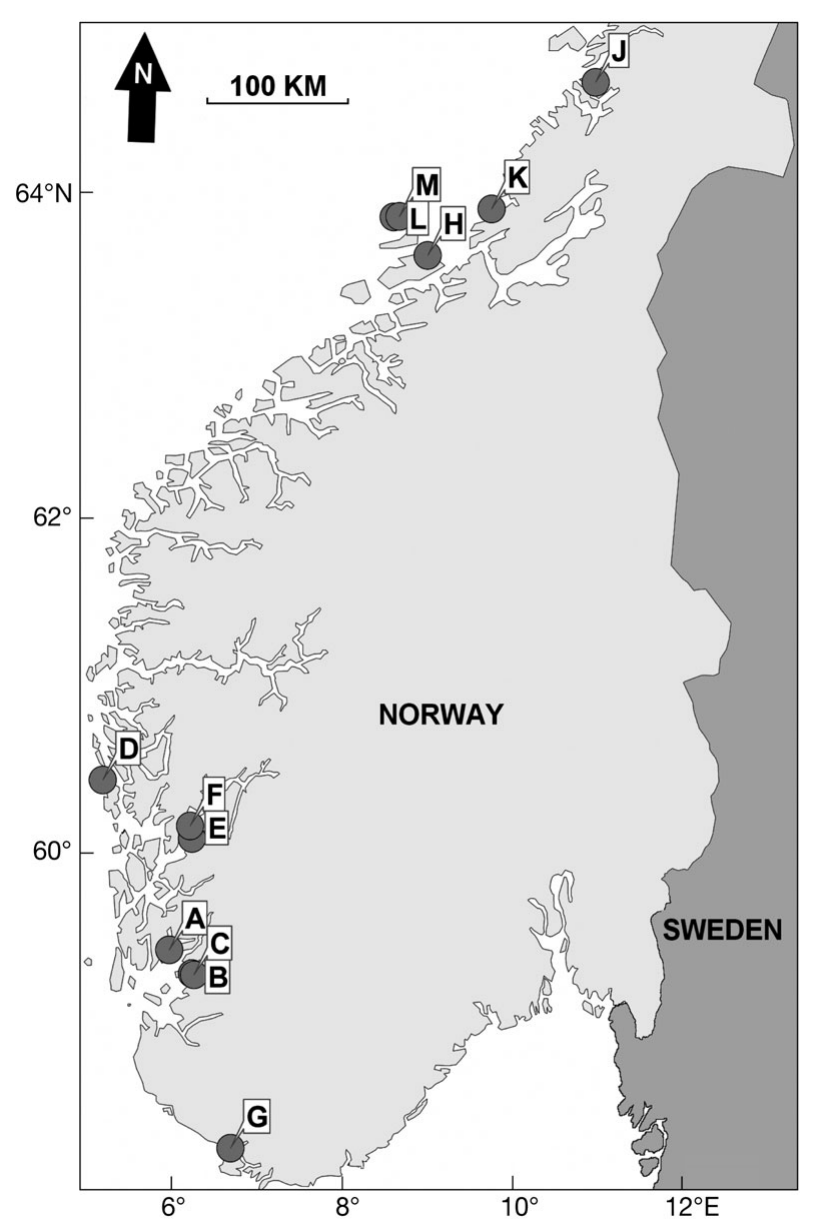

Fig. 1. Location of the 12 studied seawater farms in southwest Norway (A to $\mathrm{G}$ ) and mid-Norway ( $\mathrm{H}$ to $\mathrm{M}$ ). Note the adjacent location of Farms $\mathrm{C}$ and $\mathrm{B}, \mathrm{F}$ and $\mathrm{E}$, and $\mathrm{M}$ and $\mathrm{L}$ farms with no recognized outbreak of PGI, material was examined from the last sampling only.

Histological examination. Paraffin-embedded formalin-fixed gills were sectioned and stained with hematoxylin and eosin (H\&E) according to standard histological techniques (Bancroft \& Stevens 1996). One section through gill filaments and lamellae per fish was examined by light microscopy. Pathological changes consistent with PGI were categorized as none, slight, moderate, or extensive based on the fraction of filament length affected (approximately $<10 \%$, 10 to $50 \%$, and $>50 \%$, respectively). Epitheliocyst and parasite numbers were estimated as not detected, few, some, or many. The numbers of epitheliocysts were estimated, at $40 \times$ primary magnification, from few when far less than 1 inclusion was seen per view field to many when they were seen in the majority of view fields. PGI was diagnosed at the individual fish level when a predetermined set of criteria were met (Kvellestad et al. 2005).

DNA/RNA extraction and efficiency control. After homogenization of approximately $17.5 \mathrm{mg}$ of gill soft tissues or kidney with the Roche MagNA lyser, DNA and RNA were extracted from half the homogenate volume using the Roche High Pure PCR Template Preparation kit and Trizol ${ }^{\circledR}$ reagent (Invitrogen) in a Trizol (phenol/guanidine isothiocyanate)-chloroform extraction according to the respective manufacturer's instructions. Consistency of DNA extraction was checked in 19 random samples with the Atlantic salmon elongation factor alpha 1 gene assay (Bruno et al. 2007; our Table 1). DNA extraction efficiency was found to be essentially identical (mean \pm SD cycle

Table 1. PCR primers and probes used in the present study. Lightcycler and TaqMan probe labelling and modification are shown: donor probes (3'-Fluorescein), acceptor probes (5'-LC640 dye and 3'-phosphate), and single probe 5'-Fluorescein amidite and 3'-Black hole quencher

\begin{tabular}{|c|c|c|c|}
\hline $\begin{array}{l}\text { Primer or } \\
\text { probe }\end{array}$ & Sequence $\left(5^{\prime} \rightarrow 3^{\prime}\right)$ & $\begin{array}{l}\text { Primer set or assay specificity } \\
\text { (GenBank accession no.) }\end{array}$ & Source \\
\hline 16S RTfor & CCGCAAGGACAACTACAC & \multirow{5}{*}{$\begin{array}{l}\text { 'Candidatus Piscichlamydia salmonis' } \\
\text { (AY46224) }\end{array}$} & Present study \\
\hline 16S RTrev & ATCGACTTAGGCAGTCTCG & & Present study \\
\hline 16S RTFL & AACCCAACACCTCACGGCACGA-FL & & Present study \\
\hline 16S RTLC & 640-CTGACGACAGCCATGCAGCAC-PH & & Present study \\
\hline 16S for1 & AGTCGAACGAAATTTAAGGCAAC & & Present study \\
\hline Matrix S & GTGCCTCAATCAATATCGTT & \multirow{4}{*}{$\begin{array}{l}\text { Atlantic salmon } \\
\text { paramyxovirus } \\
\text { (EU156171) }\end{array}$} & Present study \\
\hline Matrix A & CGCAGAGTAGACCTTCTTC & & Present study \\
\hline Matrix FL & GCAGCAGACTGTATCTTTCCTAGTCC-FL & & Present study \\
\hline Matrix LC & 640-CATCGGACATTTCGTCAGGGAC-PH & & Present study \\
\hline microsporF & GGCAGTGCATCCTGATAGC & \multirow{4}{*}{$\begin{array}{l}\text { Desmozoon lepeophtherii } \\
\text { (AJ431366) } \\
\text { Domain bacteria }\end{array}$} & Present study \\
\hline microsporR & GGGTTGAATACACACACTCAC & & Present study \\
\hline A-18 & GWATTACCGCGGCKGCTG & & Suau et al. (1999) \\
\hline S-20 & AGAGTTTGATCCTCGCTCAG & & Suau et al. (1999) \\
\hline AS_ELFSTD_F & GGCCAGATCTCCCAGGGCTAT & \multirow[t]{3}{*}{ Salmonids } & Bruno et al. (2007) \\
\hline AS_ELFSTD_R & TGAACTTGCAGGCGATGTGA & & Bruno et al. (2007) \\
\hline AS_ELFSTD_P & Fam-CCTGTGCTGGATTGCCATACTG-BHQ & & Bruno et al. (2007) \\
\hline
\end{tabular}


threshold, $\mathrm{Ct}$, value: $20.7 \pm 0.6$ ), which allowed meaningful comparisons of $\mathrm{Ct}$ values for the other assays.

Real-time PCR. The 'Ca. P. salmonis' 16S rRNA gene assay was performed (on soft gill tissues) using the Faststart DNA Master Hybridization Probes kit (Roche) according to the manufacturer's recommendations with primers 16S RTfor and 16S RTrev, defining a 150bp amplicon, and fluorescence resonance energy transfer (FRET) probes (Tib-molbiol, Table 1) at a final concentration of 0.5 and $0.2 \mu \mathrm{M}$ respectively. The amplification program (Lightcycler system, Roche) was denaturation at $95^{\circ} \mathrm{C}$ for $10 \mathrm{~s}$, annealing at $61^{\circ} \mathrm{C}$ for $10 \mathrm{~s}$, and extension at $72^{\circ} \mathrm{C}$ for $10 \mathrm{~s}$. The ASPV matrix protein gene assay was performed as a 1-step RT-PCR (on soft gill tissues and kidney) using the RNA Master Hydridization Probe kit (Roche) according to the manufacturer's instructions with primers Matrix $\mathrm{S}$ and Matrix A, defining a 164 bp amplicon and FRET probes (Table 1) at a final concentration of 0.7 and $0.2 \mu \mathrm{M}$ respectively. The amplification program (Lightcycler) was denaturation at $95^{\circ} \mathrm{C}$ for $5 \mathrm{~s}$, annealing at $59^{\circ} \mathrm{C}$ for $15 \mathrm{~s}$, and extension at $72^{\circ} \mathrm{C}$ for $13 \mathrm{~s}$. The microsporidian 18S rRNA gene assay was performed using the Power SYBR green PCR master mix (Applied Biosystems) with primers microsporF and microsporR (final concentration $0.5 \mu \mathrm{M}$ ) (Table1), which defines a $95 \mathrm{bp}$ amplicon, run on the Mx3005P ${ }^{\mathrm{TM}}$ real-time PCR system using the default 2-step SYBR green with dissociation curve program. Samples examined with the latter assay were selected arbitrarily from groups with a known PGI diagnosis. Fewer fish with PGI were included as they amounted to approximately one-third of all fish from the affected farms. Negative controls using diethyl pyrocarbonate (DEPC)-treated water (Invitrogen) and a positive sample confirmed by sequencing were included in the 3 described assays.

Cloning, sequencing, and sequence analysis. The 'Ca. P. salmonis' real-time PCR amplicon was purified with the Nucleospin purification kit (Macherey-Nagel) and cloned into the TA TOPO dual promoter vector (Invitrogen) to construct a standard curve. Plasmid DNA was extracted with the Nucleospin ${ }^{\circledR}$ Plasmid kit (Macherey-Nagel) and the insert sequenced. Sequencing was performed using DYEnamic ${ }^{\mathrm{TM}} \mathrm{ET}$ terminator reagents (GE Healthcare Bio-Sciences) on the MegaBace 1000 sequencing system (GE Healthcare Bio-Sciences). Subsequent sequence analysis was performed with the Vector NTI Suite 10 software (InforMax) and NCBI blastn searches (Altschul et al. 1990).

Standard curve and assay evaluation. The vectorinsert construct, with the 'Ca. P. salmonis' real-time PCR amplicon, was linearized by HindIII digestion. A 10 -fold dilution series with a starting concentration of $95 \mathrm{ng}$ DNA $\mathrm{\mu l}^{-1}$ (equal to $2.1 \times 10^{10}$ copies $\mu \mathrm{l}^{-1}$ ) was analyzed to make a standard curve (slope $=-3.4375$, amplification efficiency $(\mathrm{E})=95.4 \%$, and $y$-intercept 37.0). The range of the observed Ct-values were divided into 3 equally large intervals and the grading scale for 'Ca. P. salmonis' load was thus not detected, low load (Ct-value $\geq 31.7$ ), moderate load, and high load (Ct-value $\leq 28.3$ ). No amplification products were identified with the 'Ca. P. salmonis' assay on testing of a taxonomically broad panel 28 different bacterial species, and blastn search of the amplicon sequence and a larger $1121 \mathrm{bp}$ amplicon produced by standard PCR and primers 16S for1-16S RTrev (Table 1) revealed $100 \%$ identity with 'Ca. P. salmonis' (GenBank accession no. AY462244, Draghi et al. 2004). Template quality was confirmed using universal bacterial 16S rRNA primers A-18 and S-20 (Suau et al. 1999; our Table 1). All real-time PCR assays' primers and probes were thoroughly examined for in silico specificity by extensive alignment and blastn searches against known sequences of public databases.

Statistical analysis. Goodman and Kruskal's gamma test, which test the strength of association of crosstabulated data when both variables are measured at the ordinal level, were done using JMP 8.0 software (SAS Institute). Median Ct-values are given for the 'Ca. P. salmonis' real-time PCR assay as their distribution is skewed and as the median is less influenced by possible outliers than the mean would be.

\section{RESULTS}

\section{Epidemiology and clinical findings in seawater-reared fish}

PGI outbreaks, as defined by the presence of pathological changes consistent with PGI combined with observation of respiratory distress and increased mortality, were detected in 6 of the 7 farms studied in southwest Norway (Fig. 1, Table 2), but not in any of the farms studied in mid-Norway. Mortality in PGI-affected farms generally started to rise 3 to 5 mo after seawater transfer and lasted for at least 1 to 3 mo. A considerable degree of variation in mortality levels between farms and even between net pens in individual farms was observed. The highest mortalities occurred at 2 sites in Boknafjorden (Farms A and B), with the highest reported being $14.7 \%$ over $32 \mathrm{~d}$ in 1 net pen. Overall water temperatures varied between 9 and $21^{\circ} \mathrm{C}$ during periods of increased mortality. In mid-August the temperature in Farms $\mathrm{A}$ and $\mathrm{B}$ rose suddenly by approximately $5^{\circ} \mathrm{C}$ to approximately $20^{\circ} \mathrm{C}$ and stayed at that level for around $10 \mathrm{~d}$. This occurred prior to or at the time when mortality started to increase and may have contributed to the high mortalities in these farms. Typically, fish with respiratory distress 'hung' in the water 
Table 2. Salmo salar L. Number of Atlantic salmon post-smolts with proliferative gill inflammation (PGI), epitheliocysts, and 'Candidatus Piscichlamydia salmonis' infection for the last sampling of the sequential study including 12 selected seawater farms in southwest Norway (A to G) and mid-Norway (H to M). A PGI disease outbreak was defined by the presence (+) of respiratory distress, pathological changes consistent with PGI, and increased mortality. For farms with duplicate results, $(+)$ and $(0)$ indicate results for fish displaying and not displaying signs of respiratory distress, respectively; otherwise, all fish at a given farm were either with or without respiratory distress

\begin{tabular}{|c|c|c|c|c|c|}
\hline Farm & Respiratory distress & PGI pathology & $\begin{array}{l}\text { Fraction of fish with } \\
\text { Epitheliocysts }\end{array}$ & 'Ca. P. salmonis' & Acknowledged outbreak \\
\hline \multirow[t]{2}{*}{$\mathrm{A}^{\mathrm{a}}$} & 0 & $3 / 10$ & $5 / 10$ & $4 / 10$ & Yes \\
\hline & + & $9 / 10$ & $8 / 10$ & $3 / 10$ & \\
\hline \multirow[t]{2}{*}{$\mathrm{B}^{\mathrm{a}}$} & 0 & $6 / 9$ & $7 / 9$ & $10 / 10$ & Yes \\
\hline & + & $9 / 9$ & $9 / 9$ & $9 / 9$ & \\
\hline $\mathrm{C}$ & 0 & $8 / 20$ & $6 / 20$ & $16 / 20$ & Yes $^{b}$ \\
\hline \multirow[t]{2}{*}{$\mathrm{D}^{\mathrm{a}}$} & 0 & $0 / 2$ & $0 / 2$ & $1 / 2$ & Yes $^{\mathrm{C}}$ \\
\hline & + & $3 / 7$ & $1 / 7$ & $3 / 7$ & \\
\hline E & + & $1 / 9$ & $2 / 9$ & $9 / 9$ & Yes $^{\mathrm{c}}$ \\
\hline \multirow[t]{2}{*}{ F } & 0 & $7 / 9$ & $6 / 9$ & $9 / 9$ & Yes \\
\hline & + & $5 / 10$ & $4 / 10$ & $10 / 10$ & \\
\hline $\mathrm{G}$ & 0 & $0 / 19$ & $2 / 19$ & $0 / 19$ & No \\
\hline $\mathrm{H}^{\mathrm{a}}$ & 0 & $13 / 18$ & $14 / 18$ & $0 / 18$ & No \\
\hline $\mathrm{J}^{\mathrm{a}}$ & + & $0 / 10$ & $7 / 10$ & $0 / 10$ & No \\
\hline $\mathrm{K}$ & 0 & $0 / 20$ & $5 / 20$ & $0 / 20$ & No \\
\hline $\mathrm{L}^{\mathrm{a}}$ & 0 & $3 / 20$ & $9 / 20$ & $0 / 20$ & No \\
\hline $\mathrm{M}^{\mathrm{a}}$ & 0 & $2 / 20$ & $18 / 20$ & $0 / 20$ & No \\
\hline \multicolumn{6}{|c|}{$\begin{array}{l}{ }^{\mathrm{b}} \text { Atlantic salmon paramyxovirus was detected, but percentage of fish with PGI and epitheliocysts was higher in a previous } \\
\text { sampling } \\
\text { cResults indicate other causes of mortality }\end{array}$} \\
\hline
\end{tabular}

close to the net pen wall, orientated against the water current, and did not eat. The gills were pale and appeared to have accumulated mucus.

\section{Histopathological findings in seawater-reared fish}

The pathological changes in fish from the 12 seawater farms varied widely and could not be unequivocally related to any observed agent. Only the major and apparently most significant pathological changes are reported here. Pathological changes consistent with PGI (our Fig. 2a-c; Kvellestad et al. 2005) were detected in fish from the 6 PGI-affected farms, predominantly in fish displaying respiratory distress, but also in some fish from 3 of the 5 apparently unaffected farms in mid-Norway. In total, $27 \%$ of all examined fish (120/438) displayed pathological changes consistent with PGI. All fish examined, irrespective of farm status, displayed slight inflammation of the lamellar epithelium especially at the apical margins, which were commonly thickened (Fig. 2d,e); these changes alone did not fulfill the criteria for PGI but could suggest unfavorable environmental conditions. On the 5 PGI-affected farms for which serial data were available, the prevalence and severity of PGI increased as the season progressed from June to December (Fig. 3a), with a peak in late September.
Epitheliocysts were observed in fish from all farms and found predominantly in the apical lamellar epithelium of non-PGI fish as well as within areas of hyperplastic interlamellar epithelium in fish with PGI, demonstrating a co-localization with pathological changes. The prevalence of epitheliocysts in the total material was 66 and $37 \%$ in fish with $(\mathrm{n}=120)$ and without $(\mathrm{n}=318)$ PGI, respectively (Table $3 a)$. A similar prevalence was observed in the 6 PGI-affected farms in southwest Norway: 66 and $33 \%$ in fish with $(n=102)$ and without $(n=229)$ PGI, respectively. When epitheliocyst number and PGI severity was compared, a moderate positive association was identified (gamma $=0.56$, Table 3a). In the 5 PGI-affected farms for which serial data were available, the prevalence of epitheliocyst infection did not apparently change significantly as the season progressed, but the number of epitheliocysts (i.e. intensity of infection) per fish appeared higher at the last sampling (Fig. 3b). At the last sampling the prevalence of epitheliocyst infection was higher in fish displaying respiratory distress than in apparently clinically healthy fish (Table 2). Number of epitheliocysts equivalent to level 3 ('many') were observed only in PGI-affected farms.

A few large multi-nucleated cells of unknown nature (Fig. 2c) were found in the gill epithelium of individual fish from 4 farms in southwest Norway, including Farm C. Such cells may be present in ASPV-infected 


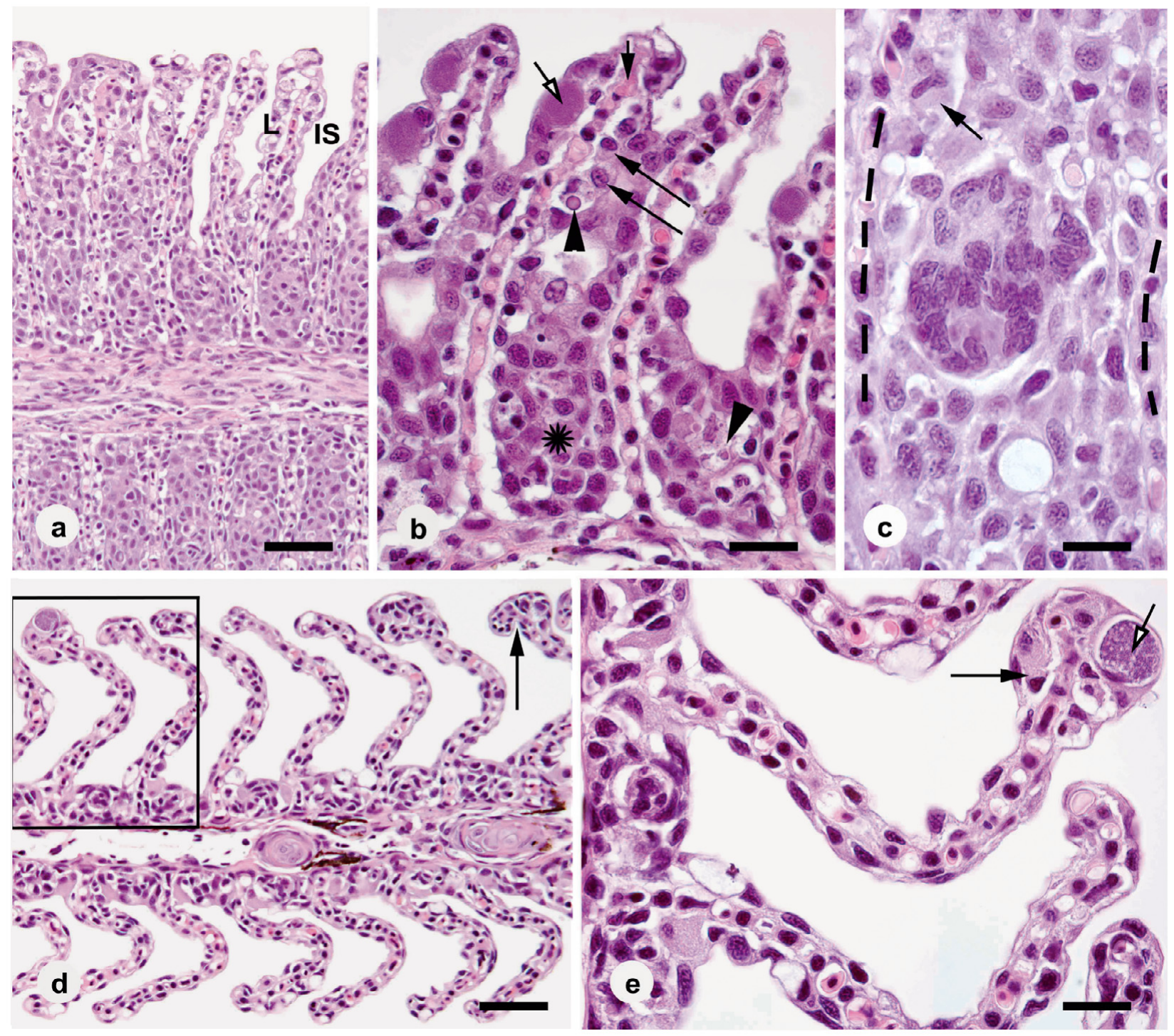

Fig. 2. Salmo salar L. Histological examination of gill sections stained with hematoxylin and eosin. (a-c) Gills with extensive pathological changes consistent with proliferative gill inflammation (PGI). Clinical signs were observed in 2 (a,b) of $3(a-c)$ fish. (a) Visible thickening of lamellae (L) and obliteration of many interlamellar spaces (IS) due to hyperplasia of epithelial cells and inflammation. Few epitheliocysts were observed elsewhere in this gill. (b) Criteria for PGI were met as there was fibrin and/or dead cells in the lamellar blood vessels (short filled arrow), and hyperplasia of epithelial cells (*), death of cells (filled arrowhead), and inflammatory cells (long filled arrow) in the epithelium. Note also the many epitheliocysts present (short unfilled arrow). (c) A large multinucleated cell of unknown nature situated in the hyperplastic interlamellar epithelium, a localization that is evident from the presence of lamellar blood vessels on each side (dashed line). Macrophage-like cells are also present (filled arrow). Atlantic salmon paramyxovirus was detected by real-time PCR in some fish from this farm. (d) Gill from a fish with no signs of disease observed, but with slight pathological changes not fulfilling PGI criteria. Some lamellae were slightly to moderately apically thickened due to epithelial changes (area in rectangle, detailed in [e]) and/or deformation of the lamellae (filled arrow). (e) Thickened margin due to basal infiltration of the epithelium with inflammatory cells, some of which were macrophage-like (filled arrow). Enlarged epithelial cells with epitheliocysts (unfilled arrow) were also observed in some of these margins. Scale bars (a) and $(\mathrm{d})=50 \mu \mathrm{m}$, and (b), (c), and (e) $=20 \mu \mathrm{m}$

cell cultures (Kvellestad et al. 2003), but it is unclear if these observations in the field material were related to viral infection. Trichodinids were the most commonly observed ectoparasite, especially in fish from the 2 farms (A and B) with the highest mortality. Their presence may, however, have been underestimated due to artefactual loss of organisms during histological processing. 

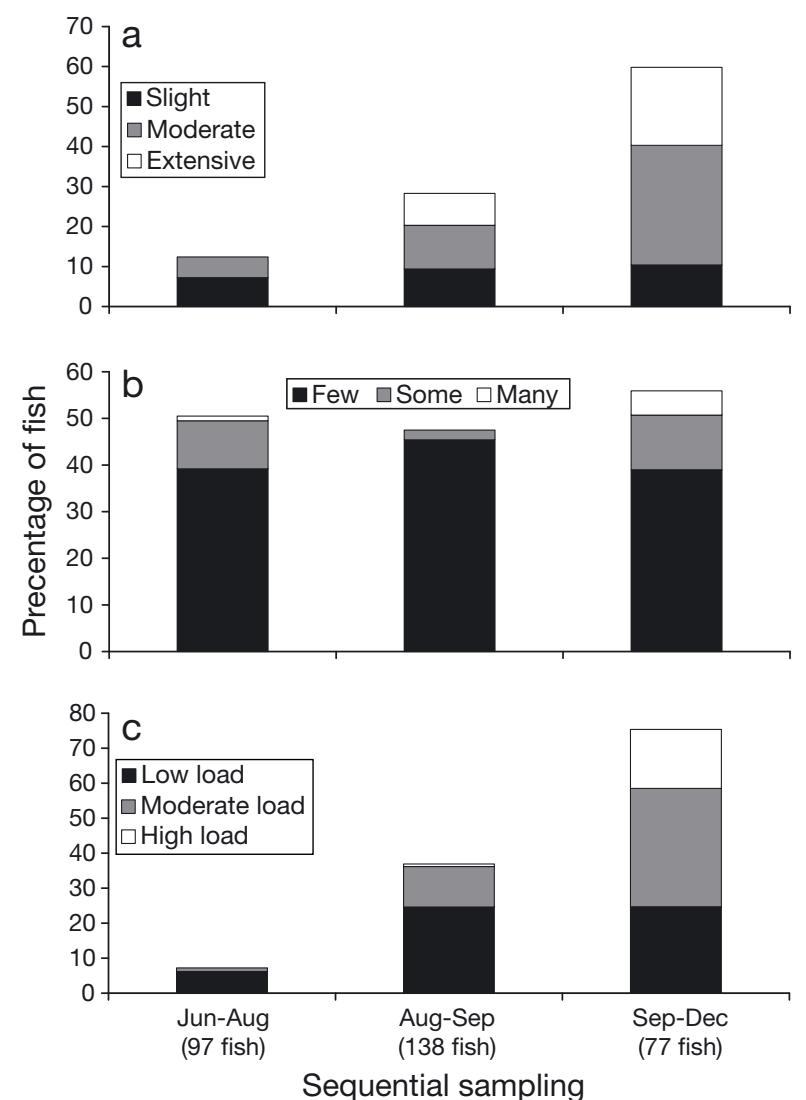

Fig. 3. Sequential data were available for 5 seawater farms in southwest Norway with proliferative gill inflammation (PGI) outbreaks; the study period was divided into 3 intervals. Prevalence is presented as percentage of sampled Atlantic salmon post-smolts with (a) PGI, (b) epitheliocysts, and (c) 'Candidatus Piscichlamydia salmonis' infection

\section{'Candidatus Piscichlamydia salmonis' detection in seawater-reared fish and comparison with histological findings}

'Ca. P. salmonis' was detected by real-time PCR in fish from the 6 PGI-affected seawater farms in southwest Norway but not in any other farm. In these farms, ' Ca. P. salmonis' infection prevalence was 56 and $33 \%$ respectively in fish with $(\mathrm{n}=102)$ and without $(\mathrm{n}=229)$ PGI, and when 'Ca. P. salmonis' load and PGI severity was compared, a moderate positive association was identified (gamma $=0.36$, Table $3 b$ ). On comparison of the 5 PGIaffected farms for which serial data were available, prevalence and severity of ' $C a$. P. salmonis' infection was also found to increase as the season progressed from June to December (Fig. 3c).

In the 6 PGI-affected farms, no association (gamma = -0.02 , Table 3c) was observed between 'Ca. P. salmonis' load by semi-quantitative real-time PCR and observed epitheliocyst numbers. 'Ca. P. salmonis' was detected in 37 and $42 \%$ of fish with $(n=143)$ and without ( $\mathrm{n}=188$ ) observed epitheliocysts, respectively. Although most fish had few epitheliocysts and the data therefore are skewed, an inverse relationship was observed to median 'Ca. P. salmonis' real-time PCR Ctvalues, when the studied material was limited to those fish in which 'Ca. P. salmonis' was detected (Fig. 4).

'Ca. P. salmonis' real-time PCR positive samples revealed Ct-values between 25.7 and 35.0. Extrapolation from the standard curve, median Ct-values, and the amount of tissue extracted identifies a modest load of 'Ca. P. salmonis' even in fish with many epitheliocysts. Dependent on 16S rRNA gene copy number per genome, a median load of approximately $\leq 1.36 \times 10^{6}$ bacteria $\mathrm{g}^{-1}$ soft gill tissues in fish with PGI is indicated.

\section{ASPV and microsporidian detection in seawater-reared fish}

ASPV was detected only in the gills and/or the kidney of 4 fish (3 with PGI), sampled at Farm C in December. It should be noted that the period between PGI diagnosis at farm level and last sampling was the longest for this farm. A selection of 66 fish from 9 of the 12 seawater farms was examined for the presence of the microsporidian Desmozoon lepeophtherii (Freeman \& Sommerville 2009). In 5 farms with PGI in southwest Norway (Fig. 5), D. lepeophtherii was detected by realtime PCR at prevalences of 100 and $81 \%$ in PGI and non-PGI fish, respectively. Median Ct-values (range: 15.2 to 31.5 ) indicate a $>30$ times higher microsporidian load in fish with PGI compared to unaffected fish. High prevalences $(77 \%)$ were also apparent in the 4 unaffected farms in mid-Norway (Fig. 5), although median Ct-values suggest the lowest observed loads in these fish. Sequencing of 6 real-time PCR amplicons from different groups of fish, as seen in Fig. 5, confirmed $100 \%$ identity with sequence in GenBank with accession number AJ431366 (Freeman et al. 2003).

\section{Freshwater stage observations}

No increased mortality or disease was reported from the 14 hatcheries which supplied smolts to the 12 studied seawater farms. Eighty smolts from 4 of the hatcheries in southwest Norway were examined by histology. These displayed slight to moderate thickening of lamellar margins due to inflammatory cell infiltration of the epithelium, while slight inflammation probably resulting from intraperitoneal vaccination was observed in 9 individuals. Gills from 120 smolts from these 4 plus 2 other hatcheries in southwest Norway were examined by real-time PCR. Although no epithe- 
Table 3. Results from examined Atlantic salmon post-smolts from the 6 seawater farms in southwest Norway with outbreaks of proliferative gill inflammation (PGI) analyzed for associations using Goodman and Kruskal's gamma test. (a) Amount of epitheliocysts vs. PGI severity (gamma $=0.56, z$-score $=4.83$ ). (b) 'Candidatus Piscichlamydia salmonis' load vs. PGI severity (gamma $=0.36, z$-score $=2.82$ ). $(\mathrm{c}){ }^{\prime} C a$. P. salmonis' load vs. amount of epitheliocysts $($ gamma $=-0.02, z$-score $=-0.26)$. The 2 positive associations can be considered statistically significant as the critical $z$-score value (at 0.01 level of significance) was \pm 2.58

\begin{tabular}{|c|c|c|c|c|}
\hline (a) Epitheliocysts & Extensive & Moderate & Slight & None \\
\hline Many & 5 & 0 & 2 & 0 \\
\hline Some & 4 & 5 & 3 & 9 \\
\hline Few & 14 & 24 & 11 & 67 \\
\hline Not detected & 5 & 14 & 15 & 153 \\
\hline (b) 'Ca. P. salmonis' load & Extensive & Moderate & Slight & None \\
\hline High & 3 & 4 & 2 & 12 \\
\hline Moderate & 10 & 9 & 5 & 25 \\
\hline Low & 5 & 10 & 9 & 38 \\
\hline Not detected & 10 & 20 & 15 & 154 \\
\hline (c) 'Ca. P. salmonis' load & Many & Some & Few & Not detected \\
\hline High & 3 & 2 & 5 & 11 \\
\hline Moderate & 1 & 4 & 17 & 27 \\
\hline Low & 0 & 0 & 22 & 40 \\
\hline Not detected & 3 & 15 & 72 & 109 \\
\hline
\end{tabular}

liocysts were observed by histology, a very low 'Ca. P. salmonis' load was detected in 8 smolts (Ct-values 32.5 to 35.3). ASPV was not detected in any smolts.

\section{DISCUSSION}

In the present study, outbreaks of PGI were confirmed in Atlantic salmon post-smolts in 6 of 7 seawater farms located within an area of southwest Norway known for recurrent PGI. Outbreaks started 3 to 5 mo

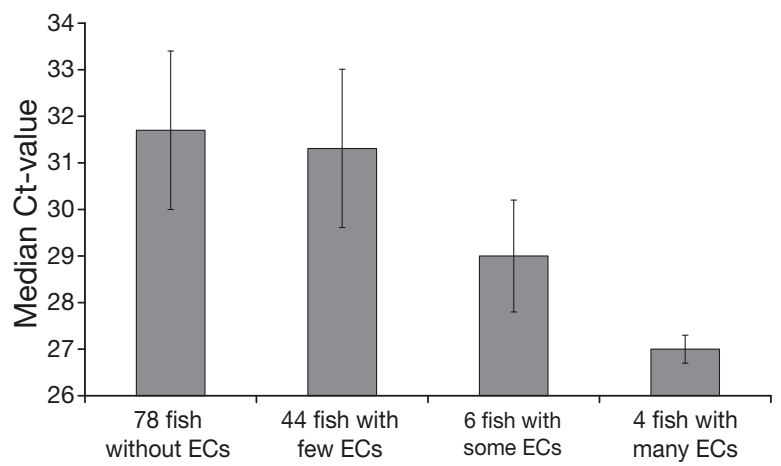

Fig. 4. Semiquantitative number of epitheliocysts (ECs) per fish compared to median cycle threshold $(\mathrm{Ct})$ values (error bars: median absolute deviation) for the 132 positive 'Candidatus Piscichlamydia salmonis' real-time PCR Atlantic salmon post-smolts from the 6 proliferative gill inflammation (PGI)affected seawater farms in southwest Norway. 'Ca. P. salmonis' load was graded as low (1, Ct-value $\geq 31.7)$, moderate (2), or high $(3, \mathrm{Ct}$-value $\leq 28.3)$ following seawater transfer in spring and lasted at least 1 to $3 \mathrm{mo}$, with variable mortality. Highest losses were identified in 2 adjacent and sheltered fjord farms following a rapid increase in water temperature.

Detection of 'Ca. P. salmonis' was systematically compared with the occurrence of PGI and the prevalence and number of histologically detectable epitheliocysts in this comprehensive and sequential material from different farms. 'Ca. P. salmonis' could not be detected by real-time PCR in any fish from the 5 unaffected farms in mid-Norway or the 1 unaffected farm in southwest Nor-

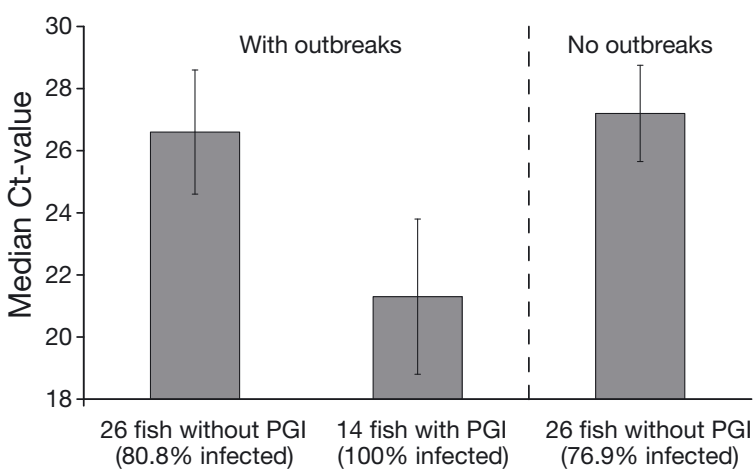

Fig. 5. Prevalence and intensity of infection with the microsporidian Desmozoon lepeophtherii in 66 farmed Atlantic salmon post-smolts from 5 Norwegian seawater farms with proliferative gill inflammation (PGI) outbreaks (fish without and with PGI) and 4 unaffected farms (only fish without PGI). Error bars represent median absolute deviation 
way. Secondly, the prevalence of both 'Ca. P. salmonis' and PGI, as well as the load and severity respectively, increased in affected farms as the season progressed. Our results also indicate a moderate positive association between 'Ca. P. salmonis' load and PGI severity in the 6 PGI-affected farms. 'Ca. P. salmonis' was identified in only $56 \%$ of fish with PGI in the 6 affected farms, and therefore obviously does not fulfill the desired criteria for molecular confirmation of microbial disease causation (Fredericks \& Relman 1996), which requires identification in essentially all cases. However, as Fredericks \& Relman (1996) also suggest, strict adherence to every criteria may not be required for a compelling argument regarding causation, particularly in the case of multifactorial etiology, as etiological agents and their associated pathological changes may not necessarily be simultaneously present. Though our data does not indicate a mechanism by which 'Ca. P. salmonis' may contribute to PGI development, some Chlamydiae are inflammation-provoking pathogens (Blasi et al. 2007, Caswell \& Williams 2007). A role could, therefore, be postulated for 'Ca. P. salmonis' in PGI similar to the now-accepted role of Chlamydophila pneumoniae in multifactorial community-acquired pneumonia (CAP) in humans (Yen et al. 2005).

While the wide distribution and similar prevalence of epitheliocysts regardless of farm status does not suggest an obvious correlation to disease, our results also indicate a moderate positive association between epitheliocyst numbers and PGI severity in the 6 PGIaffected farms. Epitheliocysts were more prevalent in fish with PGI and in fish displaying respiratory distress, and cysts tended to be directly co-localized with typical PGI-related pathological changes. This is in accordance with previous reports of epitheliocyst organisms as etiological agents of proliferative gill disease in different cultured fish species (Paperna 1977, Molnár \& Boros 1981, Miyazaki et al. 1986, Crespo et al. 1990, Nylund et al. 1998).

In light of a previous study linking epitheliocysts in seawater-reared Atlantic salmon with gill disease to 'Ca. P. salmonis' by in situ hybridization (Draghi et al. 2004), we expected to identify a strong association between detection of this bacterium and epitheliocyst observation. No such association could, however, be demonstrated, which implies that at least 1 organism other than 'Ca. P. salmonis' is responsible for many of the epitheliocysts observed in the present study. Preliminary fluorescence in situ hybridization results support this conclusion and indicate an etiological significance of other bacteria in the development of epitheliocysts (T. Steinum unpubl.). That the epitheliocysts in seawater-reared fish may have been caused by 'Candidatus C. salmonicola' (Karlsen et al. 2008) in the present study was discounted using specific PCR
(Mitchell et al. 2010). However, some association is suggested between 'Ca. P. salmonis' load and epitheliocyst numbers in those fish confirmed infected by 'Ca. P. salmonis' via real-time PCR. This indicates that 'Ca. P. salmonis' is either responsible for a proportion of the observed epitheliocysts or simply increasing in number in covariance with an unidentified epitheliocyst organism during PGI development.

ASPV was detected in only 4 fish from 1 PGI-affected farm in the present study. This was lower than encountered previously (Kvellestad et al. 2005), suggesting that there may be considerable year-to-year variation in the prevalence of this viral infection. Our results do not suggest an etiological role for ASPV in the present study material.

The high suggested prevalence of the microsporidian Desmozoon lepeophtherii (Freeman \& Sommerville 2009) regardless of fish and farm status and the substantially higher load in all examined PGI-affected fish indicate that the parasite may have a role in the development of PGI. Unlike the microsporidian and epitheliocysts, 'Ca. P. salmonis' was exclusively detected in PGI-affected farms. Phylogenetic analysis of partial 18S rDNA sequences place the parasite in a position between Nucleospora salmonis and Enterocytozoon bieneusi (Nylund et al. 2010). It could be hypothesized that the much higher load found in fish with PGI pathology could parallel the situation in humans, where opportunistic microsporidians, including Enterocytozoon bieneusi, which can be present as a prevalent low-intensity infection in healthy individuals (Nkinin et al. 2007), are capable of causing life-threatening infections in immuno-compromised patients (Sancak \& Akyön 2005).

Although both 'Ca. P. salmonis' (variable prevalence, 5 to $35 \%$ in 2 of 6 hatcheries, 20 smolt examined per hatchery) and 'Candidatus C. salmonicola' (variable prevalence, 15 to $100 \%$ in 4 of 6 hatcheries) were detected in freshwater, no mixed infections were identified and these agents could not be associated with the slight pathological changes detected. These results confirm a recent report that ' $\mathrm{Ca}$. P. salmonis' is not restricted to seawater (Draghi et al. 2010). No conclusions can be made at this stage regarding the possible contribution of freshwater infections of either 'Ca. P. salmonis' or 'Ca. C. salmonicola' to later development of PGI in seawater.

In conclusion, while the occurrence of both 'Ca. P. salmonis' and epitheliocysts showed a moderately positive association with PGI occurrence in seawaterreared fish, there was no obvious association between detection of epitheliocysts and 'Ca. P. salmonis', thus suggesting that unidentified bacteria other than recognized Norwegian CLOs (i.e. 'Ca. P. salmonis' and 'Candidatus C. salmonicola') may be present in epithelio- 
cysts in seawater-farmed Atlantic salmon. Our results suggest that infection with the microsporidian Desmozoon lepeophtherii was common, even in fish from unaffected farms, but that the considerably higher load in fish with PGI may imply a role for the parasite in disease development. Trichodinids also occurred at their highest numbers in fish with PGI. Although we have revealed associations between certain presumptive etiological agents and disease, we cannot be certain that one or more of these agents are sufficient or necessary causes of the disease or whether they contribute to pathology in fish already weakened and diseased by some other factor. Effective control of PGI requires the identification of not only immediate causes of disease, but also the underlying agents. Further research is required into the characterization of the epitheliocyst agents and the role of the microsporidian in gill disease. PGI may prove difficult to reproduce in challenge trials, so other approaches should be explored, including a continued search for novel agents, in situ detection of agents in pathological altered gill tissues, and epidemiological studies. As for community-acquired pneumonia in humans, it seems reasonable to expect the emergence of numerous etiological factors associated with PGI as examinations of this disease condition expands.

Acknowledgements. This study was funded by The Research Council of Norway (grant nos. 164771/S40 and 163427/S40) and ScanVacc AS. A special thanks to Marine Harvest Norway AS and staff members R. Nordstoga Haldorsen, S. Sværen, T. Bakke Jøssund, T. Sundet, and S. Gåsø for providing samples and information. E. Brun at the National Veterinary Institute (NVI) participated in the project design. Coworker K. Høybakk is thanked for help in the laboratory. Diagnostic investigations by colleagues at NVI regional laboratories, especially K. Flesjå and A. B. Olsen, were of great value for planning sampling. R. Bjerke Larsen and E. Skjerve, Norwegian School of Veterinary Science are thanked for their advice regarding statistical analysis, and A. Tarpai at NVI for assistance with the map.

\section{LITERATURE CITED}

Altschul SF, Gish W, Miller W, Myers EW, Lipman DJ (1990) Basic local alignment search tool. J Mol Biol 215:403-410 Bancroft JD, Stevens A (1996) Theory and practice of histological techniques, 4th edn. Churchill Livingstone, Edinburgh

Blasi F, Aliberti S, Allegra L, Piatti G and others (2007) Chlamydophila pneumoniae induces a sustained airway hyperresponsiveness and inflammation in mice. Respir Res 8:83

Bruno D, Collet B, Turnbull A, Kilburn R and others (2007) Evaluation and development of diagnostic methods for Renibacterium salmoninarum causing bacterial kidney disease (BKD) in the UK. Aquaculture 269:114-122

Caswell JL, Williams KJ (2007) Respiratory system. In: Maxie MG (ed) Jubb, Kennedy, and Palmer's pathology of domestic animals, Vol 2. Saunders Elsevier, Edinburgh, p 523-653

Crespo S, Grau A, Padrós F (1990) Epitheliocystis disease in the cultured amberjack, Seriola dumerili Risso (Carangidae). Aquaculture 90:197-207

> Draghi A II, Popov VL, Kahl MM, Stanton JB and others (2004) Characterization of 'Candidatus Piscichlamydia salmonis' (order Chlamydiales), a Chlamydia-like bacterium associated with epitheliocystis in farmed Atlantic salmon (Salmo salar). J Clin Microbiol 42:5286-5297

> Draghi A II, Bebak J, Popov VL, Noble AC and others (2007) Characterization of a Neochlamydia-like bacterium associated with epitheliocystis in cultured Arctic charr Salvelinus alpinus. Dis Aquat Org 76:27-38

Draghi A II, Bekab J, Daniels S, Tulman ER and others (2010) Identification of 'Candidatus Piscichlamydia salmonis' in Artic charr Salvelinus alpinus during survey of charr production facilities in North America. Dis Aquat Org 89: 39-49

> Evans DH (1987) The fish gill: site of action and model for toxic effects of environmental pollutants. Environ Health Perspect 71:47-58

Flesjå KI, Hjeltnes B, Johansen R, Norheim K, Olsen AB, Skjelstad HR (2004) Havbruksrapport: 1.3. Helse-situasjonen hos laksefisk. (Marine aquaculture report: 1.3. The health situation for salmonid fish). Havforskningsinstituttet (Institute of Marine Research), Bergen. Available at: www.imr.no/filarkiv/2004/03/1.3_Helsesituasjonen_hos_ laksefisk.pdf/nb-no (in Norwegian)

> Fredericks DN, Relman DA (1996) Sequenced-based identification of microbial pathogens: a reconsideration of Koch's postulates. Clin Microbiol Rev 9:18-33

Freeman MA, Sommerville C (2009) Desmozoon lepeophtherii n. gen., n. sp., (Microsporidia: Enterocytozoonidae) infecting the salmon louse Lepeophtheirus salmonis (Copepoda: Caligidae). Parasit Vectors 2:58

- Freeman MA, Bell AS, Sommerville C (2003) A hyperparasitic microsporidian infecting the salmon louse, Lepeophtheirus salmonis: an rDNA-based molecular phylogenetic study. J Fish Dis 26:667-676

Grøntvedt RN, Øvretveit S, Breck O, Brun E (2006) Risikofaktorer assosiert med proliferative gjellebetennelse (Risk factors associated with proliferative gill inflammation). Norsk Fiskeoppdrett 31:54-56 (in Norwegian)

> Hoffman GL, Dunbar CE, Wolf K, Zwillenberg LO (1969) Epitheliocystis, a new infectious disease of the bluegill (Lepomis macrochirus). Antonie van Leeuwenhoek 35: $146-158$

Karlsen M, Nylund A, Watanabe K, Helvik JV, Nylund S, Plarre H (2008) Characterization of 'Candidatus Clavochlamydia salmonicola': an intracellular bacterium infecting salmonid fish. Environ Microbiol 10:208-218

Kvellestad A, Dannevig BH, Falk K (2003) Isolation and partial characterization of a novel paramyxovirus from the gills of diseased seawater-reared Atlantic salmon (Salmo salar L). J Gen Virol 84:2179-2189

Kvellestad A, Aarflot L, Tørud B, Holm JA (2004) Proliferative gjellebetennelse hjå laks: eit undervurdert problem? (Proliferative gill inflammation in Atlantic salmon: An underestimated problem?). Norsk Veterinærtidsskr 116: 552-553 (in Norwegian)

Kvellestad A, Falk K, Nygaard SMR, Flesjå K, Holm JA (2005) Atlantic salmon paramyxovirus (ASPV) infection contributes to proliferative gill inflammation (PGI) in seawater-reared Salmo salar. Dis Aquat Org 67:47-54

> Meijer A, Roholl PJM, Ossewaarde JM, Jones B, Nowak BF (2006) Molecular evidence for association of Chlamydiales 
bacteria with epitheliocystis in leafy seadragon (Phycodurus eques), silver perch (Bidyanus bidyanus), and barramundi (Lates calcarifer). Appl Environ Microbiol 72: 284-290

Mitchell SO, Steinum T, Rodger H, Holland C, Falk K, Colquhoun DJ (2010) Epitheliocystis in Atlantic salmon, Salmo salar L., farmed in fresh water in Ireland is associated with 'Candidatus Clavochlamydia salmonicola' infection. J Fish Dis 33:665-673

Miyazaki T, Fujimaki Y, Hatai K (1986) A light and electron microscopic study on epitheliocystis disease in cultured fishes. Bull Jap Soc Sci Fish (Nippon Suisan Gakkaishi Tokyo) 52:199-202

Molnár K, Boros G (1981) A light and electron microscopic study of the agent of carp mucophilosis. J Fish Dis $4: 325-334$

Nkinin SW, Asonganyi T, Didier ES, Kaneshiro ES (2007) Microsporidian infection is prevalent in healthy people in Cameroon. J Clin Microbiol 45:2841-2846

Nowak BF, Lapatra SE (2006) Epitheliocystis in fish. J Fish Dis 29:573-588

Nylund A, Kvenseth AM, Isdal E (1998) A morphological study of the epitheliocystis agent in farmed Atlantic salmon. J Aquat Anim Health 10:43-55

Nylund A, Watanabe K, Nylund S, Karlsen M, Sæther PA, Arnesen CE, Karlsbakk E (2008) Morphogenesis of salmonid gill poxvirus associated with proliferative gill disease in farmed Atlantic salmon (Salmo salar) in Norway. Arch Virol 153:1299-1309

Nylund S, Nylund A, Watanabe K, Arnesen CA, Karlsbakk E (2010) Paranucleospora theridion n. gen., n. sp. (Microsporidia, Enterocytozoonidae) with a life cycle in the salmon louse (Lepeophtheirus salmonis, Copepoda) and Atlantic salmon (Salmo salar). J Eukaryot Microbiol 57: 95-114

Paperna I (1977) Epitheliocystis infection in wild and cultured

Editorial responsibility: Alex Hyatt,

Geelong, Victoria, Australia sea bream (Sparus aurata, Sparidae) and grey mullets (Liza ramada, Mugilidae). Aquaculture 10:166-176

Paperna I, Alves de Matos AP (1984) The developmental cycle of epitheliocystis in carp, Cyprinus carpio L. J Fish Dis 7:137-147

Paperna I, Sabnai I, Castel M (1978) Ultrastructural study of epitheliocystis organisms from gill epithelium of the fish Sparus aurata (L.) and Liza ramada (Risso) and their relation to the host cell. J Fish Dis 1:181-189

Paperna I, Sabnai I, Zachary A (1981) Ultrastructural studies in piscine epitheliocystis: evidence for a pleomorphic developmental cycle. J Fish Dis 4:459-472

Rodger HD (2007) Gill disorders: an emerging problem for farmed Atlantic salmon (Salmo salar) in the marine environment. Fish Vet J 9:38-48

> Sancak B, Akyön Y (2005) Microsporidia: general characterictics, infections and laboratory diagnosis. Mikrobiyol Bul 39:513-522 (in Turkish)

Skjelstad HR, Bornø G, Flesjå K, Hansen H, Nilsen H, Wasmuth MA, Hjeltnes B (2007) The health situation in farmed fish in Norway 2007. National Veterinary Institute, Oslo. Available at: www.vetinst.no/eng/Research/Publications/ Fish-Health-Report/Farmed-Fish-Health-Report-2007

Speare DJ, Ferguson HW (2006) Gills and pseudobranchs. In: Ferguson HW (ed) Systemic pathology of fish: a text and atlas of normal tissues in teleosts and their responses in disease. Scotian Press, London, p 24-62

Suau A, Bonnet R, Sutren M, Godon JJ, Gibson GR, Collins MD, Doré J (1999) Direct analysis of genes encoding 16S rRNA from complex communities reveals many novel molecular species within the human gut. Appl Environ Microbiol 65:4799-4807

Yen MY, Hu BS, Chen YS, Lee SS and others (2005) A prospective etiologic study of community-acquired pneumonia in Taiwan. J Formos Med Assoc 104:724-730

Submitted: March 22, 2010; Accepted: July 12, 2010

Proofs received from author(s): August 23, 1010 